Междисциплинарное сотрудничество...

УДК 070

DOI https://doi.org/10.17308/vsu.proc.law.2020.4/3183

\title{
ОСОБЕННОСТИ КОНФЛИКТНОГО ВЗАИМОДЕЙСТВИЯ В МЕДИАСФЕРЕ
}

\author{
А. М. Шестерина \\ Воронежский государственный университет \\ Поступила в редакцию 13 ноября 2020 г.
}

\begin{abstract}
Аннотация: медиатизация всех сфбер нашей жизни делает актуальньлм вопрос об участии средств массовой инфорлации в процессе урегулирования конфблктов. Расслатриваются уровни участия медиа в конббликтнол взаимодействии на всех его этапах, выявляются положительные и отрицательные последствия подключения журналистов к конбликту и возможные способь предотвращения последних. Расслатриваются инициативы международных организаций в процессе защиты журналистов, освещающих вооруженные конфбликты. Исследуется вопрос о регулировании участия медиа в освещении конббликтов на законодательном уровне.
\end{abstract}

Ключевые слова: медиаконфликтология, медиаконфликт, медиасфбера, конфбликтное взаилодействие.

\begin{abstract}
: mediatisation of all aspects of our lives makes the question of mass media participating in conflict mitigation as relevant as ever. This article reviews the levels of medias' involvement in conflict at different stages, highlights the positive and negative consequences of involving the press in it and the various methods of negating those negative consequences. We review the various initiatives from international organisations in protecting journalists covering military conflicts, explore the matter of regulating involvement of the press in conflict coverage on the judicial level.
\end{abstract}

Key words: mediaconflictology, mediaconflict, mediasphere, conflict-based interaction.

Выдающийся австрийский ученый, лауреат Нобелевской премии К. Лоренц пришел к выводу о том, что ни кометы, ни Всемирный потоп, ни экологическая катастрофа, ни ядерная зима не являются реальной угрозой для человечества. Самая страшная опасность - внутривидовая агрессия ${ }^{1}$. Человек склонен убивать самого себя - и в этом наибольшая опасность. Однако при этом важно понимать, что конфликт - естественное жизненное явление. Всё живое развивается через конфликт. Его сила может быть обращена как на разрушение, так и на созидание.

Сегодня во многом стереотип отношения к конфликту диктуется средствами массовой информации. Активное подключение медиа ко всем сфрерам нашей жизни делает их удобной площадкой для развития конфликтного взаимодействия и способом влияния на выбор модели конфликтного поведения человека. СМИ не только оказывают мощное

\footnotetext{
${ }^{1}$ См.: Лорени К. Агрессия. М., 1994.
}

(C) Шестерина А. М., 2020 


\section{Вестник ВГУ. Серия: Право}

воздействие на формирование у человека установок, влияющих на поведение в конфликтных ситуациях, но и помогают вырабатывать у людей, начиная с детства, стереотипы конструктивного поведения в проблемных ситуациях.

О том, что средства массовой информации играют значимую роль в развитии многих конфоликтных ситуаций, мировая общественность начала говорить достаточно давно. Так, уже в 1969 г. Национальная комиссия США по расследованию причин и предотвращению насилия пришла к выводу: видеопроизведения, содержащие сцены жестокости, учат человека применять насилие для достижения своих целей ${ }^{2}$. Осознавая серьезность проблемы, ученые Дж. Брайан и С. Томпсон полагают, что трансляция различных форм конфрликтного взаимодействия в медиа можно считать одной из самых крупных проблем современности именно в силу того, что такие медиасообщения во многом фрормируют модель конфликтного поведения современного человека ${ }^{3}$. Психологи Томас и Хортон отмечают: «Чрезмерно частый показ насилия по телевидению может привести к тому, что население будет все больше привыкать к насилию» ${ }^{4}$. Подтверждение тому мы находим во многих научных исследованиях и экспериментах как частного, так и общего характера. К примеру, результаты исследования, проведенного Л. Берковицем, показали прямую зависимость между трансляцией покушения на президента США Д. Форда и ростом числа угроз в адрес президента после этой трансляции ${ }^{5}$. Такой же эффект наблюдается учеными и в случаях, когда СМИ сообщают о серийных убийствах и других насильственных действиях ${ }^{6}$. Прямые и отложенные негативные эффекты трансляции информации, содержащей сцены конфликтного взаимодействия, фиксируют и такие ученые, как М. Гельман ${ }^{7}$, Г. Гербнер и Л. Гросс ${ }^{8}$, И. Дзялошинский ${ }^{9}$ и $\checkmark$ многие другие.

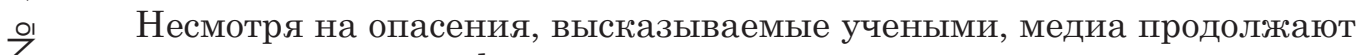
активно освещать конфликты, причем, как правило, в их кульминаци尺े онной фазе и нередко актуализируя агрессивную составляющую ${ }^{10}$. Такой

${ }^{2}$ См.: Дзялошинский И. Язык вражды в российских СМИ : социальные, культурные, профрессиональные фракторы. М., 2006. С. 9.

${ }^{3}$ См.: Брайан Дж., Толпсон С. Основы воздействия СМИ. М., 2004.

${ }_{4}$ Телевизионное насилие формирует жизненные стратегии зрителей. URL: http://www.i-news.org/viewnews/religion/16658 (дата обращения: 06.11.2020).

${ }^{5}$ Cм.: Berkowitz L. (1962). Violence in the mass media // L. Berkowitz (Ed.), Aggression: A social psychological analysis (pp. 229-255). New York: McGraw-Hill.

${ }^{6}$ См.: Дзялошинский И. Указ. соч. С. 9.

${ }^{7}$ См.: Гельлан $M$. Русский способ. Терроризм и массмедиа в третьем тысячелетии. М., 2003.

${ }^{8}$ Cm.: Gerbner G., Gross L. (1976). Living with television: The violence profile. Journal of Communication, 26, pp. 173-199.

${ }^{9}$ См.: Дзялошинский И. Указ. соч.

${ }^{10}$ См.: Телевизионное насилие фрормирует жизненные стратегии зрителей. URL: http://www.i-news.org/viewnews/religion/16658 (дата обращения: 06.11.2020). 
Междисциплинарное сотрудничество...

подход становится особенно опасным в кризисные периоды жизни социума, поскольку в подобных ситуациях зависимость аудитории от медиа возрастает, а иногда становится тотальной. $К$ примеру, в течение первой недели самоизоляции время телепросмотра у разных слоев населения увеличилось от 27 минут до 1 часа 18 минут $^{11}$. Подобные же процессы мы наблюдаем и в других традиционных и новейших медиа. В связи с этим именно сегодня представляется актуальным рассмотреть вопрос о характере участия медиа в процессе развития конфликтного взаимодействия. В нашем исследовании мы предпримем попытку изучить данный вопрос стереоскопически - в аспекте участия медиа в освещении уже существующих конфликтов и через призму анализа создаваемых ими конфликтных медийных ситуаций.

Прежде всего, важно отметить, что освещение журналистами конфрликта неизбежно. Конфликт достаточно часто объективно становится способом решения значимых социальных противоречий, и медиа вынуждены транслировать эту информацию обществу, а для большинства руководителей СМИ новости такого рода определяются как рейтинговые и желательные. Кроме того, особенности работы журналиста диктуют ему обращаться к языку конфликта. Так, стремление «достучаться» до аудитории, привлечь ее внимание к медиатексту нередко приводит к упрощению поведения, снижению гибкости, повышению нетолерантности. Конфрликт часто закладывается в основу драматургии медиапроизведений (например, активно развиваются такие форматы, как шоу конфликтов, интервью-конфронтация, спор). Наконец, эмоциональное поле, в котором работают журналисты, во многом агрессивно и поощряет резкие, прямые оценочные суждения. В результате, подходя к освещению конфрликта, журналист всякий раз оказывается перед дилеммой: объективно информировать или учитывать последствия и смягчать воздействие. Этот вопрос решается журналистом в ходе освещения всех этапов конфоликта, и с такой точки зрения журналист может содействовать его урегулированию и даже предотвращению или, напротив, провоцировать его эскалацию.

Так, на этапе предконфоликта медиа могут осуществлять диагностику проблем и вскрывать их, тем самым предотвращая конфоликт. Однако на этом же этапе постоянным обсуждением предконфликтных тем они могут формировать агрессивную концепцию среды, создавать медиаповоды для конфликтов и даже инициировать конфликты в прагматическом аспекте. Последний вариант реализуется в так называемых провокационных конфликтах, которые определяются как массмедийное (освещаемое в медиа) противоборство, имеющее целью подтолкнуть оппонента к действиям, противоречащим его же собственным интересам. Одним из первых примеров провокационного конфликта считается акция «Факел свободы», организованная Э. Бернейсом в Нью-Йорке в 1929 г. во время традиционного Пасхального марша. Суть ее заключалась в том, что

${ }^{11}$ Mediascope, TV Index, Россия 100+, домашний просмотр, полные сутки. 
Вестник ВГУ. Серия: Право

девушки из высших слоев американского общества демонстративно закурили сигареты перед журналистами, которые зафиксировали и тиражировали эту акцию с девизом «Женщины зажгли “ракелы свободы”». Последствием этого стал конфликт, изменивший отношение к курению женщин в Америке. Акция была заказана "American Tobacco Company» и имела вполне коммерческие цели. С этого момента и далее такого рода медийные конфоликты, приводящие к конфликтам реальным, получили распространение.

На этапе развития конфликта медиа также могут сыграть как позитивную, так и негативную роль. В положительном аспекте они осуществляют постоянный мониторинг конфликтных ситуаций (поскольку большая часть редакций относит такие новости к high level news) и за счет вывода их из теневой сферы нередко снижают жесткость используемых тактик и стратегий. Так, журналисты часто освещают вооруженные конфрликты, расследования по делам коррупции, расследования по делам организованной преступности, расследования по делам политической, социальной и религиозной радикализации и диктатуры. В ходе такой работы они сами нередко становятся жертвами агрессора и подвергаются насилию. В этом смысле важно наличие инициатив, которые позволяют в каком-то смысле защитить журналиста, работающего над освещением конфликтов. Так, принятая в 1949 г. «Третья Женевская конвенция» определила статус военного корреспондента - журналиста, которому одна из конфликтующих сторон разрешила следовать за вооруженными силами. Такие журналисты, в случае пленения неприятелем, считаются военнопленными и должны пользоваться защитой. В 1977 г. в «Дополнительный протокол» были заложены положения, согласно которым журналисты, находящиеся в профессиональной командировке в зоне вооруженного конфликта, рассматриваются как гражданские лица и пользуются

일 той же защитой при условии, что они не совершают никаких действий, ㅎ несовместимых со статусом гражданских лиц.

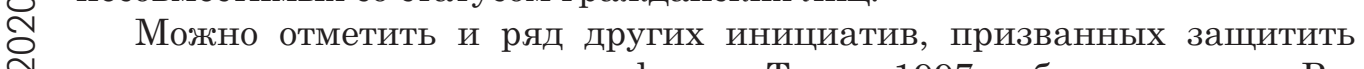
журналиста, освещающего конфликт. Так, в 1997 г. была принята Резолюция ЮНЕСКО № 29 «Осуждение насилия, направленного про-

350 тив журналистов». Резолюция призывает государства-члены не только предупреждать и расследовать преступления, касающиеся журналистов, но и принимать меры для ликвидации последствия таких преступлений. В Резолющии № 1738 Совета Безопасности (2006 г.) отмечается, что журналисты, работники средств массовой информации, находящиеся в опасных профессиональных командировках в районах вооруженного конфликта, должны рассматриваться как гражданские лица и пользоваться защитой в качестве таковых. Медельинская декларация 2007 г. призывает государства проводить независимое расследование всех актов насилия, жертвами которых стали журналисты. В Декларации об обеспечении безопасности журналистов 2009 г. требуется принятие конкретных мер на международном уровне, направленных против убийств журнали- 


\section{Междисциплинарное сотрудничество...}

стов как в мирное, так и военное время. Попытки регулировать участие СМИ в конфоликтном взаимодействии предпринимаются в таких актах $\mathrm{OOH}$, как «Хартия прав человека: всеобщая декларация прав человека», «Международный пакт о гражданских и политических правах», «Конвенция о правах ребенка" и др. Эти решения позволяют в определенной степени защитить журналиста, освещающего конфликт, и помочь ему в выполнении его профессионального долга по освещению и прогнозированию путей разрешения конфликта.

В то же время средства массовой информации могут искажать конфрликтную ситуацию, транслируя информацию о ней в противоречивой, односторонней или избирательной форме. Они могут провоцировать насилие, демонстрируя примеры его успешного применения или образцы безнаказанности. Подключение медиа к конфоликтной ситуации приводит также к расширению поля конфоликта, формированию групп поддержки и, как следствие, затягиванию конфликта и выбору участниками более жестких тактик.

На этапе завершения конфликта медиа в позитивном аспекте могут предлагать способы его разрешения, а в негативном - пролонгировать уже завершенный конфликт во времени, эксплуатировать его с целью повышения рейтингов.

Вот почему важно регулировать не только участие журналистов в конфрликтном взаимодействии, но и потенциальную возможность эскалации конфликтов в медиа. Попытки такого регулирования предпринимаются давно, в том числе на международном уровне. Так, «Европейская конвенция о защите прав человека и основных свобод» от 4 ноября 1950 г., «Международный пакт о гражданских и политических правах» от 16 декабря 1966 г. хотя и утверждают свободу средств массовой информации, подчеркивая право каждого человека на выражение своего мнения, при этом устанавливают ограничения, направленные на предотвращение возможного конфликтного взаимодействия. К примеру, ограничения в реализации этого права могут быть связаны с уважением прав и репутации других лиц или с охраной государственной безопасности, общественного порядка, здоровья или нравственности населения. Кроме того, в этих же документах речь идет и о том, что любая пропаганда войны, любое выступление в пользу национальной, расовой или религиозной ненависти, представляющие собой подстрекательство к дискриминации, вражде или насилию, должно быть запрещено законом. В документах подчеркивается, что осуществление свобод в плане информирования сопряжено с определенной ответственностью.

Все это позволяет говорить о значимости факта участия медиа в конфоликтном взаимодействии и о необходимости регулировать этот процесс на различных уровнях. Правовое регулирование такого участия, на наш взгляд, должно развиваться в двух направлениях: в направлении обеспечения свободного процесса обмена информацией и в направлении пресечения разжигания конфликтного взаимодействия на медийных 


\section{Вестник ВГУ. Серия: Право}

площадках или средствами массмедиа. Безусловно, общество имеет право быть информированным о важных в социальном плане конфликтах. Однако основная задача участия медиа в освещении конфликтов, на наш взгляд, заключается в том, чтобы изменить матрицу доказывания права через насилие.

Воронежский государственный университет

Шестерина А. М., доктор фбилологических наук, профбессор кафбедры электронных СМИ и речевой колмуникаиии

E-mail: shesterina8@gmail.com
Voronezh State University

Shesterina A. M., Doctor of Philology, Professor of the Digital Media and Vocal Communication Department

E-mail:shesterina8@gmail.com 